\title{
Spaces in-between impacts on indoor environment and energy efficiency in dwellings
}

\author{
Catarina F. T. Ribeiro ${ }^{1 *}$, Nuno M. M. Ramos ${ }^{1}$, and Inês Flores-Colen ${ }^{2}$ \\ ${ }^{1}$ CONSTRUCT-LFC, Faculdade de Engenharia da Universidade do Porto (FEUP), Rua Dr. Roberto \\ Frias s/n, 4200-465 Porto, Portugal \\ ${ }^{2}$ CERIS, DECivil, Instituto Superior Técnico (IST), Universidade de Lisboa, Av. Rovisco Pais, \\ Lisboa, 1049-001, Portugal
}

\begin{abstract}
Throughout history, it has always been recognised that the spaces in-between in dwellings have the advantage of working as environmental buffer spaces. The aim of this paper is to provide a literature review of the different spaces in-between in dwellings - balconies, shaded balconies and glazed balconies - and their impacts on comfort and on energy performance. The effects of the spaces in-between depend on their design, on the characteristics of the buildings and on the surroundings. They have important impacts on the four factors that contribute to the indoor environmental quality: thermal comfort, lighting comfort, acoustic comfort and indoor air quality. These factors are interrelated and the lack of balance between them can lead to poor indoor environmental conditions and to excessive energy consumption. Based on the review, a synthesis of the key environmental parameters that can be used as indicators for those factors is established. The impacts of spaces in-between on the factors and sub-factors of indoor environment are defined, considering different climatic regions. A holistic approach that conciliates all the abovementioned factors should be a contribution to the design of spaces inbetween in both new construction and rehabilitation projects, in order to achieve better indoor environment with minimum energy consumption.
\end{abstract}

\section{Introduction}

The balcony is a space in-between space that has the ability to influence the indoor environment quality on dwellings, working as an environmental "buffer space". Several terms has been used to define balconies ability to mediate the outdoor and the indoor environment, including: environmental filter; environmental buffer spaces; buffer zone; transitional zone; intermediate spaces and mediator space [1-3].

Nowadays, the energy reduction on dwellings is still on major importance to mitigate the role of buildings in total world energy consumption. In this regard, some recent researches are focused on the assessment of the impacts of balcony spaces on the contiguous space, in order to improve the indoor environmental quality and reduce the energy consumption without mechanical control systems [4].

* Corresponding author: catarina.cato@gmail.com 
However, it was not found in the literature any study that conciliates the whole impacts of balcony spaces on the entirety of factors that influence the indoor environmental quality.

This paper aims to provide a holistic review of the impacts of balcony spaces on the indoor environmental conditions and the energy performance of the contiguous space. Therefore, on this research the wide range of effects produced by balcony design and morphology has been systematised and their consequent impacts were analysed. Additionally, the suitability of balcony spaces for different climates is also discussed.

\section{Balcony spaces}

In order to deepen the understanding of the balcony spaces it is proposed on this research a categorisation into four typologies, according to the literature, to their morphology and to their relation to historical paradigmatic concerns. The four typologies represented on fig. 1 are: balcony (B); shaded balcony (SB); glazed balcony (GB) and eliminated balcony (EB).

These four typologies are related with a specific paradigm: the balcony (B) with the new standards of health and hygiene of the end of $18^{\text {th }}$ century; the shaded balcony (SB) to the modernist experimentalism of the first decades of the $20^{\text {th }}$ century; the glazed balcony (GB) with the demand of energy consumption reduction of the second half of $20^{\text {th }}$ century; and the eliminated balcony (EB) with the actual lack of space of contemporary high-density cities.

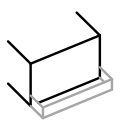

B: balcony

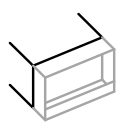

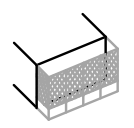

SD: shaded balcony
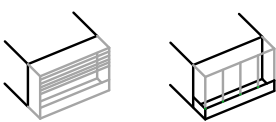

GB: glazed balcony
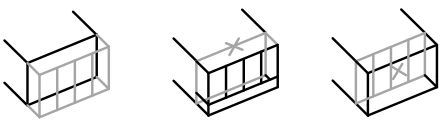

EB: eliminated balcony

Fig. 1. Balcony space typologies

\section{Balcony impacts}

\subsection{Impacts on indoor environment and energy performance}

The effects created by the balcony spaces identified on the literature are systematised on table 1, as well as the consequent impacts in the factors that contribute to the indoor environment quality (IEQ): thermal comfort, acoustic comfort, lighting comfort and air quality.

Through the analysis of the balconies impacts on table 1 it is clear that both balconies (B), and shaded balconies (SB), could improve the four factors that influence the indoor environmental quality and consequently reduce the energy consumption on buildings.

The glazed balconies (GB), in turn, can have an increased impact in the indoor environmental factors, comparing to an open balcony, mainly in thermal performance and in acoustic comfort. As it is possible to observe in fig. 2, some studies proved that in certain optimised conditions, a balcony (B) reduce the energy consumption on cooling up to $12,3 \%$ [5], while a glazed balcony (GB) reduce the energy consumption on heating up to $46 \%$ [6].

However, depending on the climatic conditions and the type of construction, the glazed spaces (GB) can compromise the indoor environmental conditions, as thermal comfort, air quality and lighting comfort. 
The elimination of the balcony space (EB) transformation on buildings, could create serious problems on the thermal comfort conditions, on indoor air quality and on lighting comfort, as well increase the energy consumption both in summer and in the winter [7] as observed on fig. 2 . 
Table 1. Balcony spaces effects and the impacts on indoor environment quality

\begin{tabular}{|c|c|c|c|c|c|}
\hline $\begin{array}{l}\text { IEQ } \\
\text { factors }\end{array}$ & & B & SB & GB & EB \\
\hline \multirow[t]{2}{*}{$\begin{array}{l}\text { thermal } \\
\text { comfort }\end{array}$} & + & $\begin{array}{l}\text { overhang effect - } \\
\text { provide solar } \\
\text { shading }[5,8,9] \\
\text { thermal barrier } \\
\text { effect - maintain } \\
\text { air temperature } \\
\text { warmer that the } \\
\text { outside air [10] } \\
\text { air flows } \\
\text { transform. effect - } \\
\text { increase the air } \\
\text { flow rate [11] } \\
\text { acoustic shield } \\
\text { effect - reduce } \\
\text { background noise } \\
\text { with doors open for } \\
\text { natural ventilation } \\
{[12,13]}\end{array}$ & $\begin{array}{l}\text { light filter effect - } \\
\text { control the passage } \\
\text { of light and reduce } \\
\text { solar gains [14] } \\
\text { air flow control } \\
\text { effect - allow } \\
\text { natural ventilation } \\
\text { while protecting } \\
\text { from light and sun } \\
{[15]} \\
\text { acoustic protection } \\
\text { effect - reduce } \\
\text { background noise } \\
\text { with doors open for } \\
\text { natural ventilation }\end{array}$ & $\begin{array}{l}\text { greenhouse effect } \\
\text { - achieve the } \\
\text { entrance of a large } \\
\text { quantity of solar } \\
\text { radiation } \\
\text { increasing thermal } \\
\text { comfort in cold } \\
\text { conditions [5-7, } 9 \text {, } \\
\text { 16-19] }\end{array}$ & - \\
\hline & - & 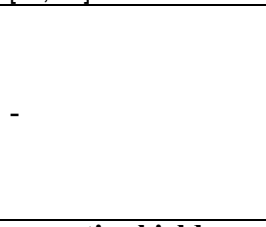 & - & $\begin{array}{l}\text { greenhouse effect } \\
\text { - can achieve } \\
\text { excessive heat } \\
\text { gains and create } \\
\text { overheating } \\
\text { problems in warm } \\
\text { conditions [20] }\end{array}$ & $\begin{array}{l}\text { loss buffer space } \\
\text { effect - increase } \\
\text { heat loss and the } \\
\text { excessive } \\
\text { penetration of } \\
\text { direct sunlight }[3 \text {, } \\
7]\end{array}$ \\
\hline \multirow{2}{*}{$\begin{array}{l}\text { acoustic } \\
\text { comfort }\end{array}$} & + & $\begin{array}{l}\text { acoustic shield } \\
\text { effect - act as an a } \\
\text { protection against } \\
\text { outdoor noise [13] }\end{array}$ & $\begin{array}{l}\text { acoustic protection } \\
\text { effect - reduce } \\
\text { background noise }\end{array}$ & $\begin{array}{l}\text { acoustic } \\
\text { protection effect } \\
\text { - act as an barrier } \\
\text { against outdoor } \\
\text { noise [2] }\end{array}$ & \\
\hline & - & & & & $\begin{array}{l}\text { loss buffer space } \\
\text { effect - loss of the } \\
\text { acoustic } \\
\text { advantages }[3,7]\end{array}$ \\
\hline \multirow[t]{2}{*}{$\begin{array}{l}\text { air } \\
\text { quality }\end{array}$} & + & $\begin{array}{l}\text { air flows transf. } \\
\text { effect - increase the } \\
\text { air flow rate [21] } \\
\text { acoustic shield } \\
\text { effect - reduce } \\
\text { background noise } \\
\text { with doors open for } \\
\text { natural ventilation } \\
\text { [13] }\end{array}$ & $\begin{array}{l}\text { air flow control } \\
\text { effect - allow } \\
\text { natural ventilation } \\
\text { while creating wind } \\
\text { protection [15] } \\
\text { acoustic protection } \\
\text { effect - reduce } \\
\text { background noise } \\
\text { with doors open for } \\
\text { natural ventilation }\end{array}$ & $\begin{array}{l}\text { greenhouse effect } \\
\text { - improve the } \\
\text { thermal insulation } \\
\text { and facilitate the } \\
\text { evaporation of } \\
\text { moistures [22] }\end{array}$ & (2) \\
\hline & - & - & - & $\begin{array}{l}\text { facade tightness } \\
\text { effect - decrease } \\
\text { the air infiltration } \\
\text { rate [23] }\end{array}$ & $\begin{array}{l}\text { condensation and } \\
\text { moisture effect - } \\
\text { cause about mold } \\
\text { and indoor } \\
\text { dampness } \\
\text { problems [3] }\end{array}$ \\
\hline \multirow{2}{*}{$\begin{array}{l}\text { lighting } \\
\text { comfort }\end{array}$} & + & $\begin{array}{l}\text { overhang effect - } \\
\text { block the } \\
\text { undesirable } \\
\text { penetration of } \\
\text { sunlight [24] }\end{array}$ & $\begin{array}{l}\text { light filter effect - } \\
\text { control the passage } \\
\text { of light reducing } \\
\text { glare discomfort [14] }\end{array}$ & & \\
\hline & - & - & - & $\begin{array}{l}\text { light barrier } \\
\text { effect - } \\
\text { decreasing the } \\
\text { daylight }[25]\end{array}$ & $\begin{array}{l}\text { loss buffer space } \\
\text { effect - cause } \\
\text { excessive } \\
\text { penetration of } \\
\text { direct sunlight [26] }\end{array}$ \\
\hline
\end{tabular}




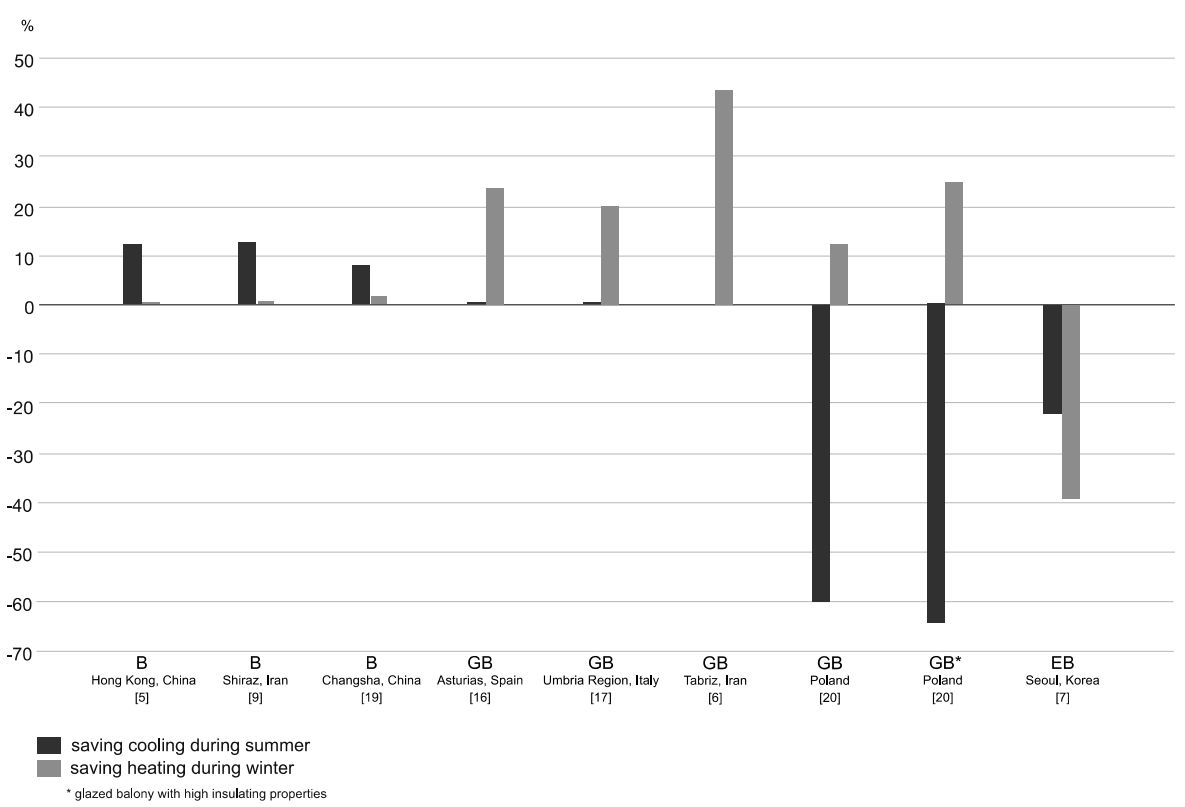

Fig. 2. Balconies impacts on energy consumption

\subsection{Balcony spaces suitability for different climates}

From the open porch of Portuguese farm houses, to the Islamic masharabiya [27], and the vernacular glazed balconies in Northern Spain, the balcony spaces had generally been related to specific climate concerns and needs. Nowadays, the spread of the scientific research about the impacts of balconies on dwellings, illustrated in fig. 3, remains related to the climatic conditions.

As it can be observed, the studies about balconies (B) have a great incidence on highdensity cities, with subtropical climate conditions, like Hong Kong [5] and Brisbane [15]. In these cities, it was verified that a balcony, or any outdoor private living space, and natural ventilation are two of the most desirable features of a living space [11] and play important roles in resident perceptions of liveability [15].

This feature has been related to the ability of balconies to have impact in diverse factors that influence the indoor environmental quality and the energy environment. In these cities where the traffic causes acoustic discomfort and poor air quality, the capacity of balconies to reduce noise, encourages to opening the windows, while the air transformation effect increases the natural ventilation. These simultaneous effects improve the thermal comfort, the air quality and contribute to a reduction of energy consumption.

In turn, the shaded balconies (SB) are for tradition related with Muslim countries, due to the capacity to comply with the harsh conditions and the desire of privacy [14]. Recent studies verified that on arid climates as the Middle East some countries have $60-70 \%$ of their energy demands allocated to cooling [28], which can justify a demand, as referred on the literature review, for the reinterpretation of the masharabiya, as a way to increase thermal comfort and reduce the energy consumption as occurred on the past.

Regarding the glazed balconies (GB), the benefits of this typology have been mainly studied in cold climate countries. The studies are focused on optimisation of the greenhouse effect, which can produce a relevant energy reduction. It was also verified that glazed balconies also plays an important role in windy and humid areas protecting the contiguous spaces of the wind while increasing the air temperature through the greenhouse effect. 
However, related to the motivation to increase the living space, reduce traffic noise, and reduce air pollution, the significant drawbacks of glazed balconies (GB) in warm climates is also being debated. It is refereed that it should not be a recommended practice in warm conditions from the analysis of the energy consumption $[14,22]$.

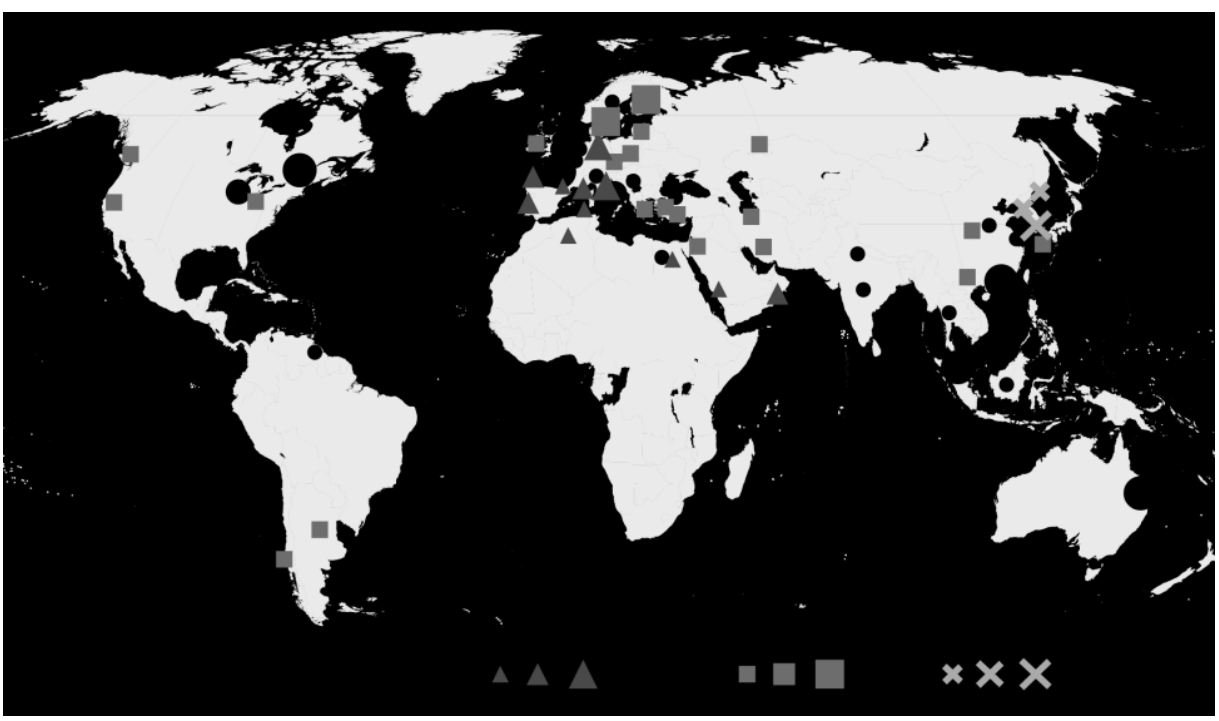

Fig. 3 Map with the researches of balconies impacts

\section{Conclusions}

The review of balcony impacts on the indoor contiguous space confirmed that all kind of balcony spaces produces relevant impacts in all the factors that contribute to the indoor environmental quality (thermal comfort, air quality, acoustic comfort and lighting comfort).

Moreover, the literature review confirmed the importance of adapting the balcony typologies to each particular climate conditions and to the near surrounding. As it became evident, an adequate and efficient design of the balcony space could contribute to improve the indoor environmental conditions and to a consequent reduction of the energy performance in dwellings, if these aspects are balanced with the occupants' preferences and the cultural concerns.

The first author would like to acknowledge the support of FCT - Fundação para a Ciência e a Tecnologia, the funding of the Doctoral Grant PD/BD/135164/2017, through the Doctoral Programme EcoCoRe. This work was financially supported by: Project POCI-01- 0145-FEDER- 007457 CONSTRUCT - Institute of R\&D In Structures and Construction funded by FEDER funds through COMPETE2020 - Programa Operacional Competitividade e Internacionalização (POCI) - and by national funds through FCT - Fundação para a Ciência e a Tecnologia.

\section{References}

1. Wing Chau, K., S. Kei Wong, and C. Yim Yiu, The value of the provision of a balcony in apartments in Hong Kong. Property Management, 2004. 22(3): p. 250-264.

2. Kim, M.-J. and H.-G. Kim, Field measurements of façade sound insulation in residential buildings with balcony windows. Building and Environment, 2007. 42(2): p. 1026-1035. 
3. Kim, J., T. Kim, and S.B. Leigh, Double window system with ventilation slits to prevent window surface condensation in residential buildings. Energy and Buildings, 2011. 43(11): p. 3120-3130.

4. Chun, C., A. Kwok, and A. Tamura, Thermal comfort in transitional spaces-basic concepts: literature review and trial measurement. Building and Environment, 2004. 39(10): p. 1187-1192.

5. Chan, A.L.S. and T.T. Chow, Investigation on energy performance and energy payback period of application of balcony for residential apartment in Hong Kong. Energy and Buildings, 2010. 42(12): p. 2400-2405.

6. Babaee, F., R. Fayaz, and M. Sarshar, The optimum design of sunspaces in apartment blocks in cold climate. Architectural Science Review, 2016. 59(3): p. 239-253.

7. Song, D. and Y.-J. Choi, Effect of building regulation on energy consumption in residential buildings in Korea. Renewable and Sustainable Energy Reviews, 2012. 16(1): p. 1074-1081.

8. Hastings, S.R., Breaking the "heating barrier": Learning from the first houses without conventional heating. Energy and Buildings, 2004. 36(4): p. 373-380.

9. Raeissi, S. and M. Taheri, Optimum overhang dimensions for energy saving. Building and Environment, 1998. 33(5): p. 293-302.

10. Hilliaho, K., et al., Glazed spaces: A simplified calculation method for the evaluation of energy savings and interior temperatures. Energy and Buildings, 2016. 125: p. 27-44.

11. Omrani, S., et al., On the effect of provision of balconies on natural ventilation and thermal comfort in high-rise residential buildings. Building and Environment, 2017. 123: p. 504-516.

12. Li, K.M., et al., A simple formula for evaluating the acoustic effect of balconies in protecting dwellings against road traffic noise. Applied Acoustics, 2003. 64(7): p. 633-653.

13. Wang, X., et al., Acoustic performance of balconies having inhomogeneous ceiling surfaces on a roadside building facade. Building and Environment, 2015. 93(P2): p. 1-8.

14. Saleh, P.H., Thermal performance of glazed balconies within heavy weight/thermal mass buildings in Beirut, Lebanon's hot climate. Energy and Buildings, 2015. 108: p. 291303.

15. Kennedy, R., L. Buys, and E. Miller, Residents' experiences of privacy and comfort in multi-storey apartment dwellings in subtropical Brisbane. Sustainability (Switzerland), 2015. 7(6): p. 7741-7761.

16. Suárez, M.J., et al., CFD analysis of heat collection in a glazed gallery. Energy and Buildings, 2011. 43(1): p. 108-116.

17. Asdrubali, F., F. Cotana, and A. Messineo, On the evaluation of solar greenhouse efficiency in building simulation during the heating period. Energies, 2012. 5(6): p. 18641880 .

18. Bataineh, K.M. and N. Fayez, Analysis of thermal performance of building attached sunspace. Energy and Buildings, 2011. 43(8): p. 1863-1868.

19. Yu, J., C. Yang, and L. Tian, Low-energy envelope design of residential building in hot summer and cold winter zone in China. Energy and Buildings, 2008. 40(8): p. 15361546.

20. Grudzinska, M., Glazed balconies as passive greenhouse systems - Potential of their use in Poland. Building Services Engineering Research \& Technology, 2016. 37(5): p. 555572.

21. Cui, D.J., C.M. Mak, and J.L. Niu, Effect of balconies and upper-lower vents on ventilation and indoor air quality in a wind-induced, naturally ventilated building. Building Services Engineering Research and Technology, 2014. 35(4): p. 393-407. 
22. Privitera, P., M. Diodato, and S. García Sáez, Solar radiation influence on premodern openings features: La Coruña and Valletta, in Vernacular Architecture: Towards a Sustainable Future. 2014, CRC Press. p. 637-642.

23. Hong, G. and B.S. Kim, Field measurements of infiltration rate in high rise residential buildings using the constant concentration method. Building and Environment, 2016. 97: p. 48-54.

24. Kim, G. and J.T. Kim, Healthy-daylighting design for the living environment in apartments in Korea. Building and Environment, 2010. 45(2): p. 287-294.

25. Wilson, M.P., O.B. Jorgensen, and G. Johannesen, Daylighting, energy and glazed balconies: A study of a refurbishment project in Engelsby, near Flensberg, Germany. Lighting Research \& Technology, 2000. 32(3): p. 127-132.

26. Shin, H.Y., G. Kim, and J.T. Kim, Effect of Occupants' Behaviour of Daylight Controls on Residential Visual Environment. Indoor and Built Environment, 2013. 22(1): p. 191-202.

27. Fathy, H., Natural energy and vernacular architecture. 1986.

28. Touma, A.A. and D. Ouahrani, The selection of brise soleil shading optical properties for energy conservation and glare removal: A case study in Qatar. Journal of Building Engineering, 2018. 20: p. 510-519. 